\title{
Question For Muslim Minorities in Absence of Islamic Banking
}

Mohammad Manzoor Malik

In the absence of Islamic banking, finance, and business laws, the economic development of some Muslims minorities is low and less vibrant. And if their economic development is somehow visible then it is for the fact of being beneficiaries of the interest-based conventional banking and financial system which could be sometimes beneficial, but with a huge toll on religious and spiritual values.

The opinions and attitudes of Muslim minorities to banking, business, and finance are shaped by the religious discourse on business and investment. In Islamic discourse, there are five main principles for business, investment, and banking: (1) prohibition on interest (riba), (2) prohibition of uncertainty (gharar), (3) prohibition on speculation or gambling (maisir), (4) restriction on activities/commodities e.g. alcohol and producing immoral and pornographic materials etc; and (5) profit and loss sharing deals and contracts. In addition to this, the nature of modern business entities, the financial institutions, and the forms of business activities are also being criticized or scholars disagree on their validity because of their very essential nature which according to religious scholars differ fundamentally from the Islamic guidelines 
and business practices as mentioned in the classics of Islamic jurisprudence.

Therefore, the religious discourse has been perplexing for public. The members of minority Muslim communities have become three types.

The first type consists of those who abstain from any involvement into banking and investment opportunities, thus they end up with loses in terms of wealth and property. However, no matter how away they keep themselves from the conventional banking, they still get trapped by it in some ways. For example, they save their money in the same banks and if they are employees then their provident funds are managed by the same system.

The second type of Muslims are those who live in self-contradiction. They believe that the current system is against their religious values, yet in fact they engage in contrary to what they believe in and therefore develop within themselves a guilty mind which is prone to open doors to many vices. Within this category are the people who are involved into business activities or want to do so as new starters, and they do not see or have any alternative that could help them out.

The third type of Muslims are those who keep their business functions limited as small tradesmen, sole proprietors, family businesses, or temporary partnerships and thus avoid to a greater 
degree financial and investment engagements with banks and financial institutions. However, this type of owners of small businesses are not always totally free from the engagements with the conventional banks and financial institutions.

\section{Is Islamic Banking the Solution?}

Islamic banking as it is being practiced remains controversial and debatable among scholars because of their mechanisms and products. And those Muslim minorities who do not even avail the facility of these Islamic banks have to find some other alternatives which could help them economically.

\section{Fact and the Question:}

The simple fact is that banks use people's money. And the question is :- are the people ready to use their own money and how? This is the question which Muslim minorities need to think over. 